\title{
The COVID-19 crisis \\ in Latin America in \\ historical perspective ${ }^{1}$
}

\author{
José Antonio Ocampo
}

\begin{abstract}
This essay compares the COVID-19 crisis in Latin America with two long-lasting crises (the Great Depression and the debt crisis) and two more recent and shorter ones (the 1997 Asian crisis and the 2008-2009 North Atlantic crisis). The analysis indicates that almost all external shocks, whether associated with external financing, the terms of trade, trade volumes or remittances, have been weaker during the current crisis. What has mainly been lacking is international financial cooperation. The severity of the crisis has therefore been due more to domestic factors: the fact that the region was the global epicentre of the pandemic for several months and that the crisis has come on top of five years of poor economic performance and three decades of slow growth. For this reason, the region needs to change its development patterns on top of implementing policies to overcome the crisis.
\end{abstract}

\section{Keywords}

COVID-19, economic crisis, international cooperation, economic growth, poverty, Latin America

\section{JEL classification}

E60, F34, F55, O19

\section{Author}

José Antonio Ocampo is a professor at the School of International and Public Affairs of Columbia University and chairperson of the Committee for Development Policy of the United Nations Economic and Social Council. He was formerly United Nations Under-Secretary-General for Economic and Social Affairs, Executive Secretary of the United Nations Economic Commission for Latin America and the Caribbean (ECLAC) and Minister of Finance of Colombia. Email: ocampo.joseantonio@yahoo.com.

\footnotetext{
This essay is partly based on the book on Latin American economic history written by the author jointly with Luis Bértola (Bértola and Ocampo, 2012) and on a recent paper on international financial cooperation with Latin America prepared for the United Nations Development Programme (UNDP) and published in CEPAL Review (Ocampo, 2020a). The author would like to thank Daniel Titelman and the staff of the Economic Development Division of ECLAC for the data provided to assist in the preparation of this essay. References to events during the current crisis draw on information available as of early November 2020.
} 


\section{Introduction}

The COVID-19 crisis will go down as the worst in Latin American economic history. Besides the drastic contraction of production activity, it will represent a setback of at least a decade in the fight against poverty and inequality. Since it was also preceded by one of the region's worst ever half-decades for economic growth and the prospects for recovery are beset with uncertainties, 2015-2024 will turn out to be another lost decade, one that may actually be worse and slightly more prolonged than the debt crisis of the 1980s. ${ }^{2}$

In this essay, I compare the current crisis with earlier episodes in Latin American history. I analyse both the evolution of production activity and the impacts of the external context - foreign trade, external financing and international economic cooperation. I also discuss some of the policies adopted to deal with the crisis. Given the length of the essay, I only include aggregate indicators for the region, although I do touch on the experiences of some individual countries in the body of the text.

The essay is divided into six sections. Following this introduction, section II reviews the evolution of Latin America's gross domestic product (GDP) since the beginning of the twentieth century in order to identify the crises that are analysed in the following sections. Section III examines the long-term evolution of commodity prices and the terms of trade in the region, one of the key determinants of the regional booms and busts discussed in section IV. Section V looks in detail at the crisis caused by the COVID-19 epidemic. Section VI concludes by summarizing its determinants from a historical perspective.

\section{The main crises in Latin American economic history}

Figure 1 provides an overview of economic growth in Latin America since the early twentieth century. As can be seen, there are five episodes during which Latin American GDP has fallen substantially: in 1914, 1930-1932, 1982-1983, 2009 and 2020. If half-decades of low growth are included, two additional episodes can be identified: the one that followed the Asian crisis of 1997, with growth of only $1.3 \%$ per year between 1999 and 2003, and the five-year period before the current crisis, 2015-2019, during which the Latin American economy grew at a rate of only $0.1 \%$ per year, with slightly negative figures in 2015 and 2016.

These crises have differed in their intensity and duration and the degree to which they have spread through the region, and in the international context in which they took place. The first crisis, that of 1914, was very much centred on the Southern Cone, especially Argentina, which only regained its 1913 level of GDP in 1922, while Chile and Uruguay did so much faster. The combination of external financing and the outbreak of the First World War explains this outcome. Mexico's economy was already relatively stagnant as a result of its revolution. Other countries were partially affected in 1914, but generally continued to grow, albeit very unevenly in the cases of Cuba and Venezuela. ${ }^{3}$ Because it was so concentrated in a particular subregion, this crisis will not be analysed in this essay.

\footnotetext{
2 The decades referred to throughout the essay correspond to the decades of the twentieth century.

3 The name "Venezuela" was changed to "Bolivarian Republic of Venezuela" on 15 December 1999, and this essay accordingly uses one or the other form depending on the year.
} 
Figure 1

Latin America: gross domestic product (GDP) growth, 1900-2020a

(Percentages)

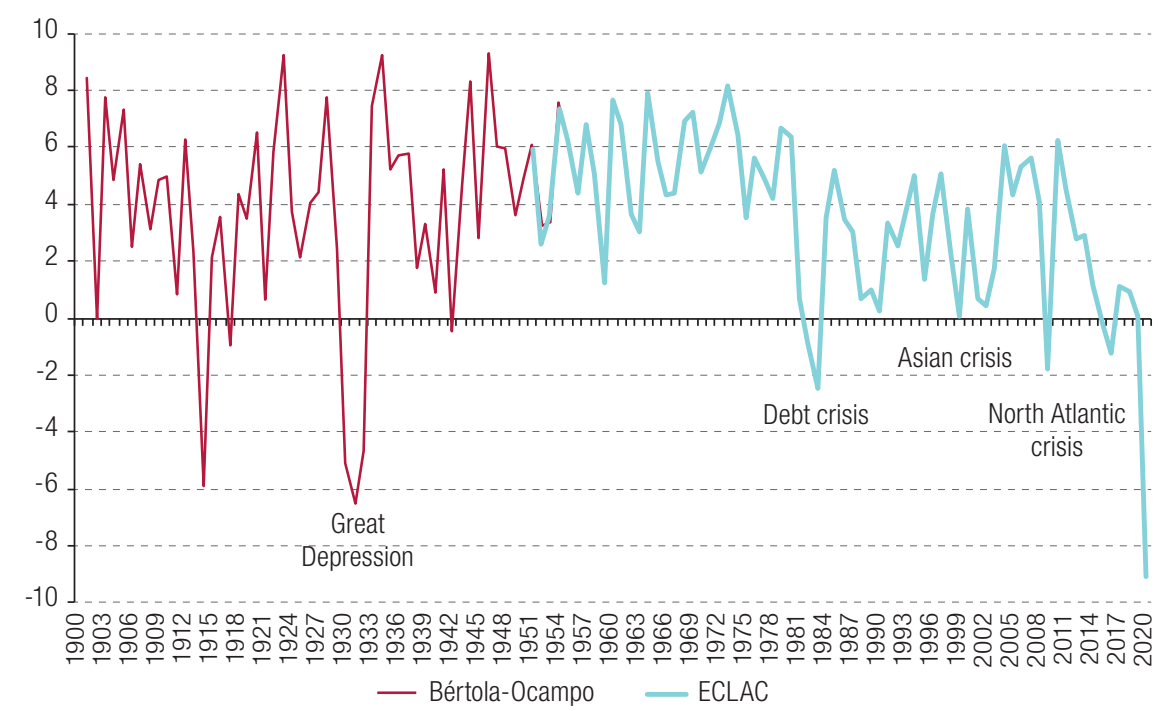

Source:Prepared by the author, on the basis of L. Bértola and J. A. Ocampo, The Economic Development of Latin America since Independence, Oxford, Oxford University Press, 2012 (for the period 1900-1949), and data from the Economic Commission for Latin America and the Caribbean (ECLAC) (for the period 1950-2020).

a Data for 1900-1949 refer to Latin America as a whole and those for 1950-2020 to a group of 10 Latin American economies: Argentina, the Bolivarian Republic of Venezuela, Brazil, Colombia, Cuba, Chile, Ecuador, Mexico, Peru and Uruguay.

The other crises spread to a larger set of countries in the region. Two of them were long-lasting: the one caused by the Great Depression of the 1930s and the Latin American debt crisis and the lost decade to which it gave rise. The most recent ones, namely those following the Asian crisis of 1997 and the North Atlantic crisis of 2008-2009, were shorter-lived. ${ }^{4}$ All of them generated external shocks related to international trade and the availability and cost of external finance, with flows of remittances from Latin American migrants also involved in the more recent ones. With the exception of the debt crisis, whose epicentre was in the region, they all derived from episodes of external origin.

Shocks associated with capital flows have been present in all the crises, albeit with different characteristics and support mechanisms to deal with them. For example, the interruption in external financing was more prolonged during the long-lasting crises than in the more recent ones, but action was also taken to reduce the amount of external debt in the former. Declines in international trade have actually occurred in certain crises but not in all of them. In particular, trade experienced a prolonged crisis during the Great Depression and short but sharp interruptions in the North Atlantic and current crises, but did not do so during the Latin American debt crisis. These issues should therefore be analysed on a case by case basis.

The evolution of commodity prices and their effects on the region's terms of trade do admit of a long-run analysis. Figure 2 shows the evolution of non-oil commodity prices and oil prices since 1900, both deflated by an index of manufacturing prices in international trade. From 1950, the Latin American goods and services terms of trade series is also presented.

\footnotetext{
4 I use this term rather than "global economic crisis" because, although its effects were global, its epicentre was in the United States and Western Europe.
} 
Figure 2

Real commodity prices (index 2015=100) and Latin American terms of trade (index 2010=100), 1900-2019



— Excluding oil $\quad$ Terms of trade $\quad$ - Oil

Source:Prepared by the author, on the basis of B. Erten and J. A. Ocampo, "Super cycles of commodity prices since the mid-nineteenth century", World Development, vol. 44, Amsterdam, Elsevier, 2013 (for commodity prices updated and deflated by the Manufacturing Unit Value Index (MUV)) and data from the Economic Commission for Latin America and the Caribbean (ECLAC) (for terms of trade for goods and services since 1950).

The evolution of the series shows that these prices experienced a deep deterioration during the two long-lasting crises. In the Great Depression, in fact, this deterioration followed on from the major collapse in commodity prices that had taken place in 1920-1921 and not been completely reversed during the international boom of the 1920s. Non-oil commodity prices fell to less than half their level prior to the collapse of 1920-1921, although oil prices fell by less than 10\%. The first of these declines was far greater than that which took place during the debt crisis, when non-oil commodity prices fell by 38\% between 1980 and 1987; oil fell by much more, but remained well above its levels of before the first oil shock in 1973. The terms of trade fell by slightly less, but the decline was still $28 \%$ between 1980 and 1986.

It is interesting to note that there was another sharp fall in commodity prices and Latin America's terms of trade in the 1960s and 1970s, exceeding that seen during the debt crisis, albeit more gradual, but its effects on economic activity were limited because of ongoing industrialization, a topic to which I will return in the next section. Lastly, the combination of the three declines referred to explains the strong long-term downward trend in commodity prices between the 1920s and the late 20th century, which corroborated Prebisch's (1973) thesis. However, this trend did not occur in the nineteenth and early twentieth centuries, nor has it recurred (so far) in the twenty-first. ${ }^{5}$

By contrast with the long-lasting crises, the shorter ones were not characterized by such adverse commodity price or terms of trade dynamics and, most importantly, these indicators recovered rapidly. During the North Atlantic crisis, moreover, there was only a temporary interruption to an upward commodity price cycle that had begun in 2003-2004 and would last until 2012-2013.

5 It is interesting to note that it was World Bank researchers (Grilli and Yang, 1988) who revived the thesis of commodity price decline in the twentieth century. See Erten and Ocampo (2013) on long-term commodity price dynamics and cycles. 


\section{The long-lasting crises}

As this analysis indicates, collapsing commodity prices were a common element in the long-lasting crises, but there was a fundamental difference: the Great Depression was a global crisis, while Latin America was the epicentre of the 1980s crisis. A comparison of the evolution of international trade and financial markets reflects these differences.

The system of world trade collapsed during the Great Depression, not only because of the direct effects of the decline in economic activity, but also because of the extensive use of protection as an adjustment mechanism. The trading system would be rebuilt gradually after the Second World War (a stage I shall refer to simply as "postwar" in the rest of this essay), using as a framework the General Agreement on Tariffs and Trade (GATT), signed in 1947, but centring initially on trade between developed countries. It should be added that the European economies had been unable to recover their economic dynamism after the First World War, and this affected the exports of the countries most dependent on them, especially Argentina. By contrast with these trends, exports supported the recovery during the debt crisis.

As is well known, the event that triggered the Great Depression was the collapse of the New York financial market, which had been at the centre of the financial boom of the 1920s and from which a number of Latin American countries had benefited. The reconstruction of an international private sector capital market would begin with the development of the so-called Eurodollar market in London in the late 1950s and would expand strongly in the 1970s thanks to the entry of more international banks into this business and to the financial surpluses of the oil-exporting countries. As figure 3 shows, the net transfer of resources to Latin America through the capital account only began to be significant in the late 1960 s and peaked at about $2 \%$ of GDP in the 1970 s.

\section{Figure 3}

Net transfers of resources to Latin America through the financial account, 1950-2019a (Percentages of GDP)

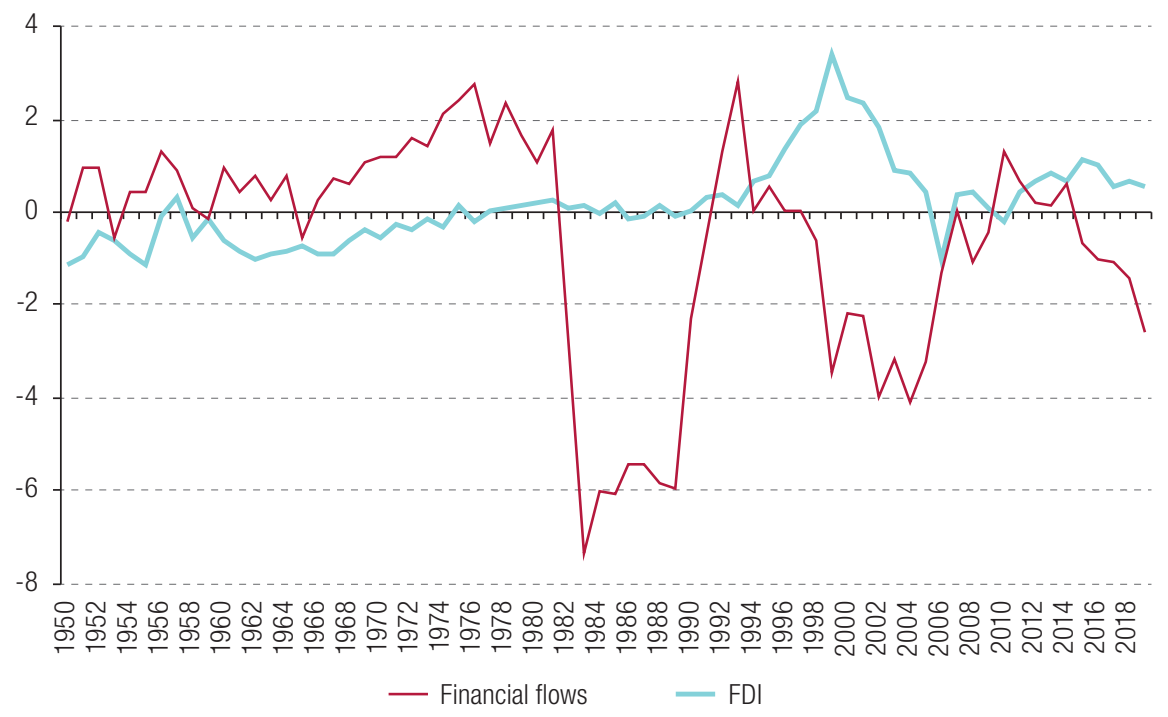

Source: Prepared by the author, on the basis of data from the Economic Commission for Latin America and the Caribbean (ECLAC). a Net transfers are estimated as the net balance of financial income minus the net balance of financial services. 
The collapse that took place, especially after the Mexican moratorium of August 1982, and that led to the debt crisis, was monumental, representing a transfer of resources abroad of some $6 \%$ of GDP between 1983 and 1989. This means that the reversal of capital flows acted as a massive shock, equivalent to $8 \%$ of regional GDP. In contrast to the Great Depression, however, the capital outflow was specific to the region and not a global phenomenon.

One point of great interest is that in both cases measures were taken to reduce external debt. During the Great Depression, the suspension of debt service by Latin American countries was part of an international process, supported even by successive United States governments. A total or partial moratorium for Latin America began in 1931 and covered all countries except Argentina, which had to agree to continue paying its debt to British creditors as part of its trade commitments to the United Kingdom, and Venezuela, which had paid off all its external debt by the early 1930s (Bértola and Ocampo, 2012, chapter IV). ${ }^{6}$

For its part, as one element of the policies adopted to secure the support of the Latin American countries for the allies during the Second World War, the United States Government pursued what proved to be a generous foreign debt renegotiation. The best settlement was that of Mexico in 1941, when it obtained a $90 \%$ reduction in the value of its debt, including that resulting from the nationalization of American investments in oil and railways. The debts owed by the other countries were not reduced, but interest payments were, and unpaid interest was not capitalized. Eichengreen and Portes (1989, table 2.1) have estimated that the region ultimately paid an effective interest rate of just over $3 \%$ on debts taken out in the 1920s, between 4 and 5 percentage points lower than the terms under which they were contracted. This meant that, as a region, they had the best outcome of all countries that had had capital market access in the 1920s. ${ }^{7}$

Measures were also taken to assist Latin American countries during the debt crisis of the 1980s, but they were modest and belated, basically because of the risk of bankruptcy for international banks, and especially those of the United States. ${ }^{8}$ There were, of course, many "silent moratoriums" in the form of temporary arrears on commercial and bilateral debt service payments, but strong pressure from the industrialized countries and multilateral agencies led Latin American countries to renegotiated agreements favourable to commercial banks (Altimir and Devlin, 1994; Devlin, 1989). At the same time, the United States and other industrialized countries put pressure on the International Monetary Fund (IMF) and the multilateral development banks to provide more financing. This was particularly important in the Baker plans of 1985 and 1987, but the amounts they provided were modest compared to the massive reversal of private capital flows and came with unprecedented "structural" conditionality (market reforms and fiscal adjustments that were often draconian). ${ }^{9}$ The final phase came in March 1989 (i.e., almost seven years after the start of the crisis) with the Brady Plan, which included a modest reduction in debt balances, and whose main effect was to renew access to private external financing (see figure 3).

The combined impact of the collapse of international trade and commodity prices and the reversal of capital flows was devastating in terms of access to foreign exchange during the 1930s. Despite the export revival which began in 1933 (although it was curbed by the macroeconomic adjustment measures adopted by the United States in 1937), the purchasing power of exports and imports was still between $30 \%$ and $40 \%$ below 1929 levels when the decade ended, and more than 20\% below that level at the

6 By 1935, 97.7\% of all dollar bonds issued by Latin America were in default, if Argentina's are excluded. Even by 1945, when some countries had renegotiated their obligations, $65.0 \%$ of non-Argentine debt remained in that situation (United Nations, 1955, table XII).

7 See also the estimates by Jorgensen and Sachs (1989) for the reduction in the present value of external debt as a result of these renegotiations.

8 At the beginning of the crisis, Latin American debt was equivalent to $180 \%$ of the capital of the nine largest United States banks.

9 In addition to increased funding, the second Baker Plan included a policy of debt buybacks and swaps, as well as exit bonds with low interest rates. 
end of the Second World War. In contrast, the purchasing power of exports did not decrease during the 1980s and in fact started to increase in the second half of the decade. The greatest adverse effect was the need to generate large and persistent trade surpluses to repay external debt, in accordance with the programmes agreed with the commercial banks (Bértola and Ocampo, 2012, figures 4.1 and 5.5).

Even more importantly, the combination of macroeconomic policy measures and structural reforms was much more favourable in the 1930s. ${ }^{10}$ The definitive abandonment of the gold standard in the region and worldwide made it possible to adopt expansionary fiscal and monetary policies in the 1930s, after an initial period of firm adjustment under the rules associated with the maintenance of parity between national currencies and gold. In contrast, the fiscal adjustment to deal with the large deficits that had built up before the debt crisis, the explosion of inflation in many countries because of currency depreciation and the adjustment programmes agreed with the IMF led rather to the adoption of austerity policies during the debt crisis.

From a structural point of view, the Latin American countries were forced to refocus on their domestic markets during the 1930s, carrying out both manufacturing and agricultural import substitution. This reorientation towards domestic markets resulted in a strong economic recovery from 1933 onward that was partly arrested at the end of the decade and in the early years of the Second World War but accelerated again at the end of the War and in the early postwar years, now supported by a commodity price boom (see figures 1 and 2). Although economic growth was not very rapid during the 1930s (2.2\% per annum in 1929-1939), it was among the best in the world. ${ }^{11}$ If the Second World War years are included, Brazil, Colombia, Mexico and Venezuela had the best growth performance.

Industrialization, which had already taken off in some countries in the late nineteenth and early twentieth centuries, put down deep roots, now with firm support from the State, and led after the Second World War to average annual growth of $5.6 \%$ in the period 1945-1980, the highest and most stable in Latin American history. Not all countries benefited alike; in particular, those of the Southern Cone lagged behind the other countries of the region. ${ }^{12}$

The debt crisis led to a very different pattern of development, characterized by economic liberalization and more vigorous integration into the world economy. Average growth between 1980 and 1990 was just $1.4 \%$ a year, much lower than in the 1930s. Colombia, which entered the crisis with low levels of foreign debt, was the best performer, along with Chile in the second half of the decade, after its severe contraction at the start of the crisis. Some countries, including Argentina and Peru, actually ended the decade with a lower level of economic activity than in 1980.

Although export performance was generally good, economic growth in 1990-2019 averaged just 2.6\% a year, i.e., a little under half that achieved during the era of State-led industrialization. It was also the worst performance of any developing region (excluding the Caribbean). ${ }^{13}$ Only a handful of Latin American countries have grown more since 1990 than during the previous period, essentially those that performed most poorly during the industrialization era (Bolivia, ${ }^{14}$ Chile and Uruguay, with Argentina performing slightly less well in the recent period than it did historically). Brazil and Mexico experienced a sharp slowdown from one period to the next, even though their policies for integration into the world economy differed.

10 On the 1930s and 1980s, see the study edited by Thorp (1988) and ECLAC (1996), as well as Bértola and Ocampo (2012, chaps. IV and V).

11 As a reference, according to Maddison's (2010) historical data, Western Europe grew by 1.5\% per year on average in 1929-1940 and the United States by $0.9 \%$.

12 See the study edited by Cárdenas, Ocampo and Thorp (2000).

${ }^{13}$ According to United Nations data, excluding the Caribbean, which grew by $2.1 \%$ per year, the only other region to perform so poorly was sub-Saharan Africa, which grew at $2.8 \%$ per year.

${ }^{14}$ The name "Bolivia" changed to "Plurinational State of Bolivia" on 7 February 2009, so this essay uses one or the other form depending on the year. 
One of the basic reasons for the weaker performance was the "premature deindustrialization" of the region's countries, as this began at a much lower level of per capita income than in the industrialized countries when they entered a similar process (Palma, 2005). Another factor has undoubtedly been greater susceptibility to economic crises, reflected in the volatility of economic growth over recent decades, which has been higher than it was during the industrialization period and even somewhat higher than was typical in the early decades of the twentieth century. ${ }^{15}$ We shall turn our attention to recent crises in the following sections.

\section{The two recent crises}

The two recent crises had very different origins. The first was the result of the Asian crisis of 1997, which spread to other emerging economies following Russia's moratorium on its foreign debt in August 1998. This crisis strongly affected Latin America and especially several South American countries. Mexico had already been affected by a homegrown crisis at the end of 1994, although this was short-lived thanks to direct support from the United States. The North Atlantic crisis had its epicentre in the United States and Western Europe, and resulted from the difficulties faced by several banking institutions, especially the investment bank Lehman Brothers, which went bankrupt in September 2008.

The international support provided to address the first crisis was of the traditional variety: financing for the affected countries through IMF and multilateral development banks. The intense controversy that arose around the IMF adjustment programmes led to a major reform of conditionality in 2002, centring it on macroeconomic variables (IMF, 2002). In addition, the Group of 20 (G20) was established so that finance ministers and central bank governors could cooperate to promote international financial stability. In 2001-2002, an attempt was made to negotiate the creation of a mechanism for renegotiating sovereign debts within IMF, but the process failed because of opposition from the United States (which had originally proposed the negotiations) and from Brazil and Mexico, among other debtor countries, because they considered that it could lead to an increase in the cost of external financing. What was agreed instead was the inclusion of collective action clauses in bond issues to facilitate debt renegotiations with private creditors. ${ }^{16}$

By contrast, the North Atlantic crisis gave rise to one of the most ambitious packages of international economic cooperation in history, adopted by the G20 now at the heads of State level. In particular, the G20 Global Plan for Recovery and Reform agreed by the G20 and adopted in London on 2 April 2009 (G20, 2009) led to the most significant reform of IMF credit lines in the organization's history, to the largest ever issue of IMF special drawing rights (SDRs), to the capitalization of the multilateral development banks and a massive increase in their lending, to an ambitious reform of financial regulation and to a commitment not to use trade protectionism as an adjustment measure, in order to avoid the deepening of the crisis that had taken place during the Great Depression. More belatedly, the G20 also embarked on efforts to strengthen international tax cooperation (a task it entrusted to the Organization for Economic Cooperation and Development (OECD)), the adoption (in 2012) of the so-called IMF "institutional vision" regarding capital flows (IMF, 2012) and the expansion and redistribution of IMF quotas; this last unfortunately took five years owing to the delay by the United States Congress in approving the necessary resources. ${ }^{17}$

\footnotetext{
15 In 1901-1929, average annual growth was 3.9\%, the standard deviation was 3.2\% and the coefficient of variation was 0.82 . In 1945-1980, the first two figures were $5.6 \%$ and $1.8 \%$ and the coefficient of variation was 0.32 . The equivalent estimates for 1990-2019 are growth of $2.6 \%$, a standard deviation of $2.2 \%$ and a coefficient of variation of 0.87 .

${ }^{16}$ In parallel, but not associated with the crisis, there were two initiatives for the reduction of poor countries' debt: the 1996 Heavily Indebted Poor Countries Initiative and the 2005 Multilateral Debt Relief Initiative. Bolivia, Honduras and Nicaragua benefited from the latter (as did Haiti, which is not included in the analysis of this essay).

17 See Ocampo (2017) for a detailed analysis of these topics.
} 
The United States Federal Reserve also launched a currency swap programme, primarily with the central banks of other developed countries, but also including four emerging economies (Brazil, Mexico, the Republic of Korea and Singapore), although only temporarily. This was in addition to the expansionary monetary and fiscal policies adopted by developed countries and the very aggressive policies of China.

For Latin America, the successive Asian and Russian crises of 1997-1998 triggered a new wave of portfolio capital outflows that was almost as prolonged as the one that took place during the debt crisis, but somewhat less severe, with net resource transfers abroad that fluctuated between $2 \%$ and $4 \%$ of GDP, as compared to the $6 \%$ seen during the 1980 s (see figure 3). This was partly offset by a boom in foreign direct investment in the region during the early years of the crisis, largely associated with privatization processes. At the same time, the cost of financing rose sharply, especially after the Russian moratorium of August 1998, reaching levels of $12 \%$ to $14 \%$ for about five years, as reflected in J.P. Morgan's Emerging Market Bond Index (EMBI), whose evolution since 1998 is shown in figure 4. Furthermore, the problems encountered by the adjustments in Argentina and Brazil meant that these costs remained high for a longer period than in other emerging economies.

Figure 4

Yields of Latin America bonds compared with those of emerging economies, 1998-2020 (Percentages)



Source: Prepared by the author, on the basis of data from J.P. Morgan.

Note: Daily data from 31 March 1998 to 9 November 2020.

Neither foreign trade nor the terms of trade were significantly affected during this crisis. The net result was five years of slow growth rather than a recession, with just one year of zero growth in 1999 (see figure 1). Argentina, the Bolivarian Republic of Venezuela and Uruguay did face a contraction during this five-year period, and a larger set of countries went into recession in 1999, including Colombia for the first time since the Second World War.

The North Atlantic crisis, like the long-lasting ones, did involve shocks in both financial and trade flows, combined with a sharp contraction in remittances from Latin American migrants. Thanks to the aggressive measures taken by the G20, however, the interruption to external financing was very moderate and short-lived for Latin America (see figure 3), and bond yields, which rose sharply after the collapse of Lehman Brothers as bond prices fell, had already normalized by the end of 2009. Moreover, the low interest rates that began to prevail in developed countries generated capital flows to emerging economies, including those of Latin America, especially between 2010 and 2014. Capital outflows from China interrupted this boom in 2015. 
International trade initially underwent a sharp contraction during the North Atlantic crisis, in fact the worst of the postwar period, with world exports falling by nearly $20 \%$ in volume and $30 \%$ in value compared to the first half of 2008 (see figure 5). This contraction dragged down the corresponding indicators for Latin America, although with value falling by more than volume, owing to the drop in commodity prices. Once again, the G20 measures helped to bring about a rapid recovery and initiate a period of growth in international trade, albeit at the lowest rates since the end of the Second World War: $3.1 \%$ per annum in volume terms in 2007-2019, as compared to $7.3 \%$ in 1986-2007. ${ }^{18}$ Latin America's export recovery was much stronger than the world average, supported by the renewal of the commodity price boom which, as seen at the end of section II, had begun in 2003-2004 and would last until 2012-2013, as well as by strong growth in sales of goods from several countries of the region to China.

Gráfico 5

International trade indices

(First half of 2008=100)

A. Exports by volume

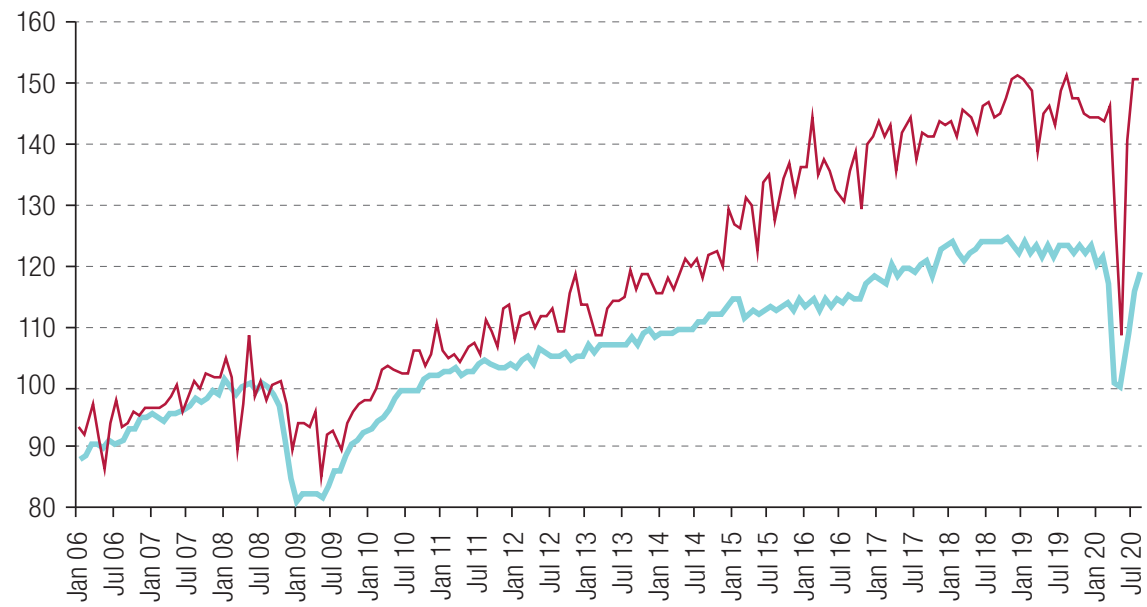

B. Exports by value



— Latin American exports by volume _ - World exports by volume

Source: Prepared by the author, on the basis of Netherlands Bureau of Economic Policy Analysis (CPB), World Trade Monitor [online database] https://www.cpb.nl/en/worldtrademonitor.

${ }^{18}$ Estimates based on data from IMF and the United Nations, respectively. 
Interestingly, the most lasting impact of this crisis was on the remittances of Latin American migrants. These stagnated in 2008 and fell by $14 \%$ in 2009, according to ECLAC data, and only in 2015 did they return to and slightly exceed the levels of 2007-2008.

The impact of this crisis on Latin America was significant in 2009, when GDP fell by $1.8 \%$. Half the region's countries went into recession that year, with particularly severe downturns in the Bolivarian Republic of Venezuela and Mexico. However, recovery was rapid and strong, and in 2010 the region grew by $6.2 \%$; only in the Bolivarian Republic of Venezuela did output continue to contract that year. However, the region's growth rate slowed substantially from 2011, even though external financing conditions and terms of trade became favourable. Moreover, as noted in section II, 2015 saw the start of one of the worst five-year periods in Latin American economic history.

\section{The COVID-19 crisis}

The coronavirus (COVID-19) crisis is unique in history, because it combines the worst pandemic since the so-called Spanish flu of 1918 with a highly integrated world economy. Its direct effects have been a virtual shutdown worldwide of some economic activities (tourism, air passenger traffic, live cultural activities) and a sharp contraction in others (retail, restaurants and various other services) because of confinement measures and cautious behaviour adopted to avoid contracting the virus. These effects, which are impacting supply in a number of sectors, have also had repercussions on aggregate demand via reduced employment, lower household incomes and households' cautious approach to spending because of income uncertainty. While macroeconomic policies have been expansionary, especially in developed countries, the combination of these supply and demand effects in an integrated world has had dramatic consequences.

According to the latest projections available at the time of writing, IMF (2020c) estimates a decline in global GDP at market exchange rates of $4.7 \%$ in $2020 .{ }^{19}$ The deep recession experienced by China in the first quarter of 2020 and the steeper recessions in a large set of countries in the second quarter reflect the devastating effects of confinement on economic activity.

The crisis is truly global and will be much severer than the North Atlantic crisis (a 2.0\% contraction of the world economy in 2009 at market exchange rates, according to IMF), as the current one has affected all countries, while that of 2008-2009 did not have such a strong impact on a large group of emerging and developing economies. The contraction has been faster than during the Great Depression, but may be shallower and, above all, much less prolonged. ${ }^{20}$ The baseline forecast by IMF is for $4.8 \%$ growth in 2021 , but this would not fully compensate for the 2020 recession in most economies. This projection assumes, in any event, that the effects of the pandemic will gradually dissipate, but there is clearly uncertainty about the consequences of further outbreaks, which have already begun to occur in the European countries and the United States.

Given the magnitude of the crisis, developed countries have been adopting policies that include increasing public spending, reducing or postponing tax payments and providing businesses with liquidity, financing and credit guarantees. In both fiscal and monetary terms, IMF estimates that the policy packages are more aggressive than those adopted to deal with the North Atlantic crisis, although with differences between countries (IMF, 2020a, 2020b and 2020c). In contrast, China's reactivation measures have been less substantial than those adopted then, owing to the reduced fiscal leeway and higher levels of debt that it has today, two issues that affect many other emerging and developing economies. In the case of the Latin American economies, this is due both to the fiscal policies adopted

\footnotetext{
${ }^{19}$ The IMF estimates $-4.4 \%$ at purchasing power parity, but this is not comparable with the estimates at market exchange rates of the United Nations, the World Bank and most private analysts.

20 This is particularly true for the United States, where the economy contracted for three consecutive years during the Great Depression - with a cumulative fall of $27 \%$ according to historical figures presented by Maddison (2010) - and only returned to 1929 levels a decade later. In Western Europe, it took six years for GDP to return to 1929 levels.
} 
to cope with the North Atlantic crisis and to the less restrictive attitudes in this respect since then and the effects of slow economic growth during the five years preceding the current crisis.

The international debate has highlighted the fact that, while the pandemic affected Western Europe and the United States early on and was slower to reach developing countries, the latter are more socially vulnerable. There are many reasons for this: health systems are of poorer quality and do not cover the entire population; informal working is rife and implies that confinement leaves a large group of workers without income; poor households live in small spaces and sometimes without proper access to water; and support mechanisms for the poor are non-existent or limited. On top of all this, there is less fiscal leeway and governments' access to credit is more restricted. For this reason, there is agreement on the need to adopt ambitious policies to support emerging and developing economies. The resource needs of these countries were estimated at US\$ 2.5 trillion at the beginning of the crisis by both IMF (2020d) and UNCTAD (2020a).

In view of the magnitude of the international crisis and the financial needs of emerging and developing economies, G20 leaders committed at the end of March to "do whatever it takes" and use all available policy tools to minimize the economic and social damage generated by the pandemic, restore global growth and maintain market stability (G20, 2020a). The finance ministers and central bank governors of the G20 member countries said much the same in their statement at the meetings of the Bretton Woods institutions (G20, 2020b). However, the international cooperation agreed so far has been very limited, in terms of both the measures taken and the resources to which emerging and developing economies will have access.

The contrast with the ambitious agenda agreed by the G20 in 2009, which was referred to in the previous section, is striking (Ocampo, 2020b). As regards IMF, resources have been secured through loans by countries to the Fund, but not through increased quotas; the expansion and reallocation of quotas was postponed in 2019 until 2023, and no decision has been made to accelerate the process. The United States vetoed the allocation of SDRs during the meetings of the Bretton Woods institutions. The only major reform of IMF has been the speeding up of approval for emergency loans to a wide range of countries, but for a small amount (about 80 countries and US $\$ 30$ billion), as the maximum authorized is the amount of each country's quota. It should be added that the Federal Reserve renewed its currency swap line, including the same emerging economies as had had access to it during the previous crisis, and added to this a repo mechanism allowing the Federal Reserve to buy any Treasury bonds that countries wish to sell it.

In contrast to 2009, there has been no call to capitalize the multilateral development banks. Fortunately, two of them, the World Bank and the African Development Bank (ADB), were capitalized in 2018 and 2019, respectively. Where debt is concerned, although there have been calls for far-reaching action, ${ }^{21}$ the only significant measure has been the agreement to postpone poor countries' debt service payments until mid-2021, ${ }^{22}$ so far without the participation of private creditors. There has also been a call to refrain from using trade protection as an adjustment mechanism, although the tensions of the so-called "trade war" between the United States and China continue.

It should be noted that cooperation measures have been particularly limited in relation to middle-income countries, a classification that includes almost all the Latin American countries. Financial cooperation with the countries of the region has indeed been very restricted (Ocampo, 2020a). On a positive note, Chile and Peru have been granted access to the IMF flexible credit line and Colombia's credit line has been renewed and increased (Mexico's was renewed at the end of 2019).23 This contingency line is intended to supplement international reserves and not necessarily to be disbursed; Colombia was the

\footnotetext{
${ }^{21}$ For the proposals on debt, see in particular Bolton and others (2020), Reinhart and Rogoff (2020) and UNCTAD (2020b).

22 This initially covered only 2020. In October, the G20 announced an extension until June 2021 and a programme that could reduce the debt of these countries, to be implemented on a case by case basis (G20, 2020c).

${ }^{23}$ With the increase in the line for Colombia, Chile has resources equivalent to 10 times its quota, Colombia and Peru 6 times and Mexico 5 times.
} 
first country to announce the possibility of using some of these resources. Also worth noting are the successful renegotiations of Argentina and Ecuador's debts with implicit IMF support, the new credit granted to Ecuador, and the ongoing negotiations between Argentina and IMF to modify the country's financing line. It should be added that no resources have been requested from the Latin American Reserve Fund (FLAR, according to its Spanish acronym) and that its board opposes their use for fiscal purposes, something that is possible with IMF resources.

In addition, several Latin American economies have had access to IMF emergency lines, but for limited amounts. Lending by multilateral banks has increased, but the two that provide the most funding to countries in the region, the Inter-American Development Bank (IDB) and the Development Bank of Latin America (CAF), need to be capitalized to play as active a role as they did in the recovery from the North Atlantic crisis. The Central American Bank for Economic Integration (CABEI) was recently capitalized.

The limitations of international cooperation contrast with the ambitious domestic policies adopted by developed countries. This is particularly true of the United States, whose policies have been much more aggressive than those it adopted in response to the North Atlantic crisis. Its limited support for international cooperation also contrasts with the leadership it exercised then. European countries have also adopted markedly countercyclical policies, but have been more open to multilateral cooperation. The contrast between the aggressive domestic economic policies of the developed countries and limited international cooperation is undoubtedly the most striking feature of the current crisis (Ocampo, 2020b).

As in the previous crisis, the effects on financial markets were initially devastating. However, the magnitude of the intervention by developed country central banks, and especially the Federal Reserve, meant that the falls were not as severe as in 2008-2009 and that financial markets were able to recover from late March onward, albeit with high levels of volatility (IMF, 2020b). One of the initial effects was the worst outflow of portfolio capital from emerging economies in history, exceeding US $\$ 100$ billion (Brooks and Fortun, 2020; IMF, 2020b). However, as shown in figure 6, after the massive capital outflow during March, bond markets in hard currencies (particularly dollars) opened for emerging economies again in April 2020, especially from the middle of that month. As a result, 12 Latin American countries, a number of public companies and the multilateral banks based in the region have been able to access this market. Capital outflows from local currency bond markets also began to decline in April, and flows turned positive in June. The outflow of equity capital also began to decline in June, and the flow turned positive in October.

Figure 6

Capital flows into emerging economies

(Billions of dollars)

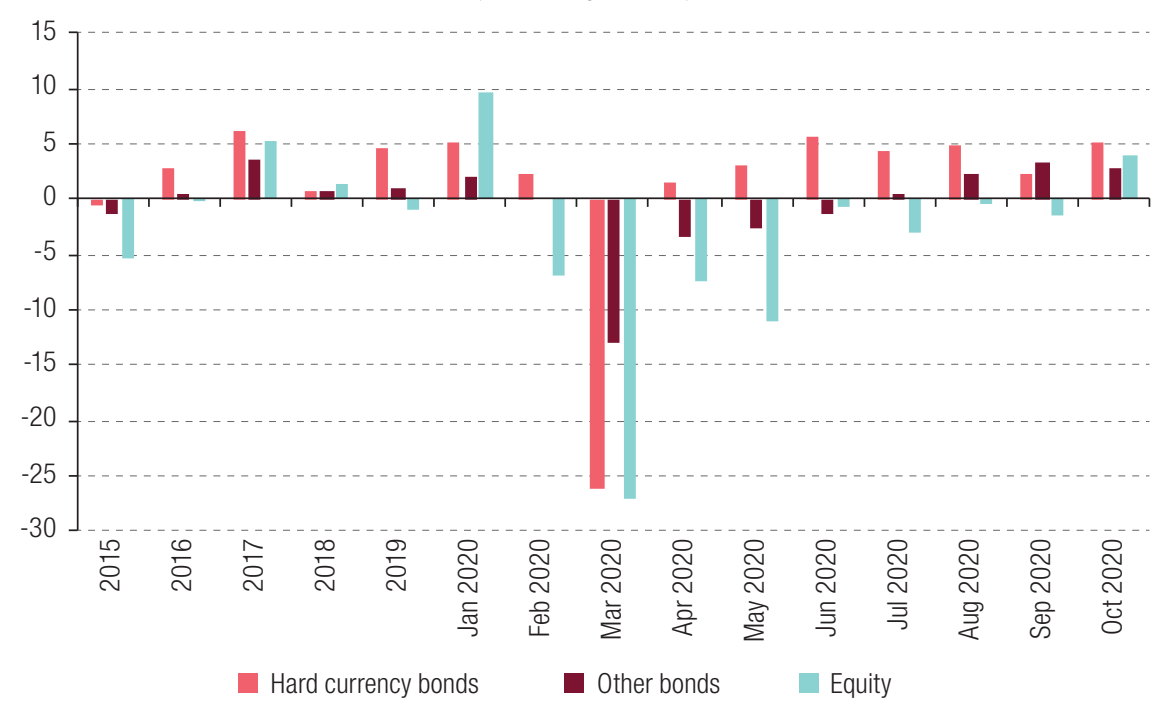

Source: Prepared by the author, on the basis of data from J.P. Morgan. 
In addition, the collapse of emerging market bond prices in secondary markets drove yields sharply upward at the beginning of the crisis, but the growing demand for such securities caused yields to fall from the end of March 2020, so that by August they were back to levels similar to those prior to the crisis. This also meant that conditions for new issues were very favourable; indeed, several countries in the region have been able to issue bonds under the best conditions ever. The normalization of access to bond markets for Latin American countries has therefore been much faster than in previous crises: some 2 months, as compared to 12 months after the North Atlantic crisis and 5 and 8 years after the Asian and debt crises respectively.

The crisis also led to a sharp contraction in international trade, intensifying the fall in volume and value terms that had begun in late 2019 as a result of the "trade war" and expectations of a global economic slowdown. ${ }^{24}$ The World Trade Organization (WTO, 2020) estimated in April that the fall in trade volumes would be between 13\% in the baseline scenario and $32 \%$ in the worst case scenario. The fall in May was $18 \%$ in relation to the average volume for 2019, in the mid-range of the WTO estimates, but there has been a strong recovery, a much faster one indeed than was experienced after the North Atlantic crisis (see figure 5). In the case of Latin America, the initial fall was steeper, but the subsequent recovery has been too. In any case, the slowdown in trade growth since the North Atlantic crisis is likely to worsen. The main uncertainty relates to the destruction or contraction of international value chains. However, to the extent that the companies involved in such chains move closer to consumers, this trend could benefit Latin America. ${ }^{25}$ As regards commodities, the crisis has led to a sharp reduction in the prices of oil and other energy products, an effect which, as we have seen, is detrimental to some Latin American countries but beneficial to others. There was also a decline in base metal prices in the early months, although this was less pronounced and was subsequently reversed, and a mixed trend in the case of agricultural commodities. Overall, then, the only commodity prices to have fallen substantially have been those of energy products. ${ }^{26}$

On top of these adverse shocks, a drop in remittances was initially expected. The available data indicate, however, that although there has been a decline for countries whose migrants are in South American countries, remittances received by the region as a whole were up by $9.6 \%$ in January-August 2020 compared to the same months in $2019 .{ }^{27}$ This increase compares very favourably with the sharp fall they experienced during the North Atlantic crisis.

Projections by IMF (2020e) and ECLAC (2020b) indicate that the region will experience a severe recession in 2020; indeed, that it will be the worst among developing countries, along with India's, and one of the worst in the world along with that of Western Europe. The data in figure 1 suggest that this will be the worst recession in Latin America's history. All the projections also indicate that recovery in 2021 will be only partial. Brazil and Chile are expected to be the least affected of the medium-sized and large countries in the region, but several smaller economies are expected to experience more limited contractions in economic activity.

On the social front, the problems have been considerable (ECLAC, 2020a). Inadequate investment is reflected in weak and fragmented health-care systems that have not ensured universal access for the population in many countries. Because of the large digital divide, students from poor backgrounds cannot benefit from virtual education. Meanwhile, the prevalence of informal working has meant that a high proportion of households, especially those that are not poor but are vulnerable to falling into

${ }^{24}$ Data from the Netherlands Bureau for Economic Policy Analysis (CPB), on which figure 5 is based, indicate that growth in the 12-month moving average of the volume of global exports was negative from October 2019, while that of global export values has been negative since August 2019.

25 See the analysis by The Economist Intelligence Unit (2020).

${ }^{26}$ See the data in International Monetary Fund (IMF), "IMF primary commodity prices", undated [online] https://www.imf.org/en/ Research/commodity-prices. World Bank (2020) projections for the whole year follow this pattern.

27 The data refer to 13 Latin American countries for which ECLAC has information: Brazil, Colombia, Costa Rica, Dominican Republic, Ecuador, El Salvador, Guatemala, Honduras, Mexico, Nicaragua, Paraguay, Peru and the Plurinational State of Bolivia. 
poverty, have been left without income and have not necessarily been reached by assistance in the form of conditional transfers. Some countries have introduced forms of limited support for these households. Many micro, small and medium-sized enterprises are failing, which is of great concern, as they generate a high proportion of employment in the region.

Overall, ECLAC estimates, as reported by the United Nations (2020), indicate that the poor population will increase by 45 million people, representing the loss of a decade and a half's progress in this area. This will coincide with likewise considerable increases in unemployment and informal jobs. These adverse trends are occurring, moreover, in a context where social conditions have been deteriorating since 2014 as a result of poor economic performance during the five years preceding the crisis.

It should be stressed that, in economic terms, the response of the countries of the region has been in line with international trends, but the scale of support has generally been much more modest than in developed countries. Central banks have provided liquidity (with obvious restrictions in countries that have dollarized economies). Governments have adopted fiscal programmes, most particularly to provide support to the health-care sector and to poor and vulnerable households, and measures to reduce or defer payment of some taxes, but the size of the packages has been variable. According to IDB estimates, the largest ones as a percentage of GDP have been those of Brazil, Chile, El Salvador and Peru (Pineda, Pessino and Rasteletti, 2020). Some countries have launched credit lines or credit guarantees on a large scale, most notably Chile, Colombia, Peru and Uruguay.

The greatest constraint has been the limited fiscal space available to the countries of the region. The contrast with their situation in the previous crisis is striking. On average, according to ECLAC data, countries had primary central government deficits of between $0.5 \%$ and $1 \%$ of GDP in the last five years compared to a surplus of more than $2 \%$ before the 2008 crisis, and national government debt of $46 \%$ of GDP compared to $29 \%$ in 2008 . Differences in fiscal space have also been highlighted by several IDB analysts (see, for example, Izquierdo and Ardanaz, 2020).

\section{In conclusion: the current crisis in perspective}

The external shocks experienced by Latin America have been sharp and have taken place in a context of limited international financial cooperation, especially by comparison with the North Atlantic crisis. However, they have been less severe than in previous crises, particularly in the cases of private external sector financing and the terms of trade. In the latter case, the sharp fall in oil prices has obviously affected oil-exporting countries but has benefited a larger set of oil-importing countries. There was an initial contraction in the volume of international trade, although a less severe one than during the North Atlantic crisis (or the Great Depression, which is not an appropriate comparison in this case). It is possible that the limited trade dynamism which has characterized the world economy since then will be accentuated, but there could be opportunities for some countries in the region from the relocation of value chains. Remittances from migrant workers have also performed much better than during the North Atlantic crisis. On the whole, then, external shocks have been less adverse in the COVID-19 pandemic than during the two long-lasting crises and even than during the shorter ones.

This means that the severity of the crisis has been due more to internal factors in the Latin American countries. Among them should be included the fact that the region became the global epicentre of the pandemic between June and August (at the time of writing, the regional trend was favourable and the epicentre was shifting to other regions). Similarly, national policy constraints, characterised by inaction or limited action in some cases, and more generally by weaknesses in health-care systems and an inability to adopt more aggressive fiscal policies, also help explain the adverse outcome. 
Even more important is the fact that, as seen in previous sections, the crisis hit the region after five years of poor performance. This helps explain why, instead of a two- or three-year crisis, the region will experience a new lost decade in 2015-2024. Moreover, the crisis closes three decades of slow economic growth, during which the region has been the worst-performing in the developing world.

This indicates that, looking beyond the current crisis, the region's development patterns need to be fundamentally changed, as has been pointed out by the United Nations (2020) on the basis of ECLAC contributions, and by the Latin American Consensus 2020 (Casilda Béjar and others, 2020). As these documents point out, the COVID-19 crisis should serve as a starting point for reformulating the region's development strategy, starting with seven basic objectives: (i) improve social policies and boost decent employment, with the aim of reducing high levels of inequality; (ii) to that end, increase public expenditure, financing this with more progressive tax structures; (iii) adopt more active production development policies underpinned by an aggressive research and development strategy; (iv) pursue stronger countercyclical policies that reduce the vulnerability of economies to crises; (v) implement a strategy of deep regional integration that can help diversify production activity in a context of slow growth in international trade; (vi) adopt an ambitious environmental policy conducive to compliance with international agreements on combating climate change and protecting diversity; and (vii) most importantly, firmly uphold democratic values and institutions.

\section{Bibliography}

Altimir, O. and R. Devlin (1994), "Una reseña de la moratoria de la deuda en América Latina", Moratoria de la deuda en América Latina, O. Altimir and R. Devlin (comps.), Buenos Aires, Fondo de Cultura Económica.

Bértola, L. and J. A. Ocampo (2012), The Economic Development of Latin America since Independence, Oxford, Oxford University Press.

Bolton, P. and others (2020), "Necessity is the mother of invention: how to implement a comprehensive debt standstill for COVID-19 in low- and middle-income countries", London, Centre for Economic Policy Research (CEPR), 21 April [online] https://voxeu.org/article/debt-standstill-covid-19-low-and-middleincome-countries.

Brooks, R. and J. Fortun (2020), "COVID-19 capital flow exodus from EM", Global Macro Views (GMV), No. 3830, Washington, D.C., Institute of International Finance (IIF), 2 April.

Cárdenas E., J. A. Ocampo and R. Thorp (eds.) (2000), Industrialisation and the State in Latin America: the Post War Years, Volume Three of An Economic History of Twentieth Century Latin America, Houndmills, Palgrave, 2000.

Casilda Béjar, R. and others (2020), "El Consenso Latinoamericano 2020: una nueva visión para la era post COVID-19", Documentos de Trabajo, DT 29/2020, Salamanca, Instituto de Iberoamérica [online] http:// americo.usal.es/iberoame/sites/default/files/Consenso\%20Latinoamericano\%202020.pdf.

Devlin, R. (1989), Debt and Crisis in Latin America: The Supply Side of the Story, Princeton, Princeton University Press.

ECLAC (Economic Commission for Latin America and the Caribbean) (2020a), "The social challenge in times of COVID-19", Special Report COVID-19, No. 3, Santiago, 12 May.

(2020b), "Addressing the growing impact of COVID-19 with a view to reactivation with equality: new projections", Special Report COVID-19, No. 5, Santiago, 15 July.

(1996), América Latina y el Caribe quince años después: de la década perdida a la transformación económica, 1980-1995, Santiago, ECLAC/Fondo de Cultura Económica.

Eichengreen, B. and R. Portes (1989), "After the deluge: default, negotiation, and readjustment during the interwar years", The International Debt Crisis in Historical Perspective, B. Eichengreen and P. H. Lindert (eds.), Cambridge, Massachusetts, The MIT Press.

EIU (The Economist Intelligence Unit) (2020), "Will Latin America take advantage of supply chain shifts?", August [online] https://www.eiu.com/n/campaigns/will-latin-america-take-advantage-of-supply-chain-shifts/.

Erten, B. and J. A. Ocampo (2013), "Super cycles of commodity prices since the mid-nineteenth century", World Development, vol. 44, Amsterdam, Elsevier. 
Grilli, E. R. and M. C. Yang (1988), "Primary commodity prices, manufactured goods prices, and the terms of trade of developing countries: what long run shows", The World Bank Economic Review, vol. 2, No. 1, Oxford, Oxford University Press, January.

G20 (Group of 20) (2020a), "Extraordinary G20 Leaders' Summit: statement on COVID-19”, paper presented at the Extraordinary G20 Leaders' Summit, Riyadh, 26 March [online] http://www.g20.utoronto.ca/2020/2020g20-statement-0326.html.

(2020b), "Communiqué", paper presented at the Virtual Meeting of the G20 Finance Ministers and Central Bank Governors, Riyadh, 15 April [online] http://www.g20.utoronto.ca/2020/2020-g20-finance-0415.html. (2020c), "Communiqué", paper presented at the Virtual Meeting of the G20 Finance Ministers and Central Bank Governors, Riyadh, 14 October [online] https://g20.org/en/media/Documents/FMCBG\%20 Communiqu\%C3\%A9_English_140ctober2020_700pm.pdf. (2009), "Global Plan for Recovery and Reform", paper presented at the G20 Leaders' Summit, London, 2 April [online] http://www.g20.utoronto.ca/2009/2009communique0402.html.

IMF (International Monetary Fund) (2020a), Fiscal Monitor: Policies to Support People during the COVID-19 Pandemic, Washington, D.C., April.

(2020b), Global Financial Stability Report: Markets in the Time of COVID-19, Washington, D.C., April. (2020c), World Economic Outlook Update, Washington, D.C., June.

(2020d), "Press briefing by Kristalina Georgieva following a conference call of the International Monetary and Financial Committee", Washington, D.C., 27 March [online] https://www.imf.org/en/News/Articles/2020/03/27/ tr032720-transcript-press-briefing-kristalina-georgieva-following-imfc-conference-call. (2020e), World Economic Outlook: A Long and Difficult Ascent, Washington, D.C., October.

(2012), The Liberalization and Management of Capital Flows: An Institutional View, Washington, D.C., 14 November.

(2002), Guidelines on Conditionality, Washington, D.C., 25 September [online] https://www.imf.org/ External/np/pdr/cond/2002/eng/guid/092302.pdf.

Izquierdo, A. and M. Ardanaz (2020), "Fiscal policy in the time of coronavirus: constraints and policy options for Latin American and Caribbean countries”, Ideas Matter, Washington, D.C., Inter-American Development Bank (IDB), 31 March [online] https://blogs.iadb.org/ideas-matter/en/fiscal-policy-in-the-time-of-coronavirusconstraints-and-policy-options-for-latin-american-and-caribbean-countries/.

Jorgensen, E. and J. Sachs (1989), "Default and renegotiation of Latin American foreign bonds in the interwar period", The International Debt Crisis in Historical Perspective, B. Eichengreen and P. H. Lindert (eds.), Cambridge, Massachusetts, The MIT Press.

Maddison, A. (2010), "Maddison database 2010", Groningen Growth and Development Centre [online] https:// www.rug.nl/ggdc/historicaldevelopment/maddison/releases/maddison-database-2010.

Ocampo, J. A. (2020a), "La cooperación financiera internacional frente a la crisis económica latinoamericana", CEPAL Review, No. 131 (LC/PUB.2020/9-P), Santiago, Economic Commission for Latin America and the Caribbean (ECLAC), August.

(2020b), Weak International Economic Cooperation in Response to the COVID-19 Crisis, Brussels, Foundation for European Progressive Studies (FEPS)/Initiative for Policy Dialogue (IPD), September. (2017), Resetting the International Monetary (Non)System, Oxford, Oxford University Press.

Palma, G. (2005), "Cuatro fuentes de 'desindustrialización' y un nuevo concepto del 'síndrome holandés'”, Más allá de las reformas: dinámica estructural y vulnerabilidad macroeconómica, J. A. Ocampo (ed.), Bogotá, Economic Commission for Latin America and the Caribbean (ECLAC)/Alfaomega [online] https:// repositorio.cepal.org/bitstream/handle/11362/1875/S3301015M_es.pdf?sequence=1\&isAllowed=y.

Pineda, E., C. Pessino and A. Rasteletti (2020), "Política y gestión fiscal durante la pandemia y la post-pandemia en América Latina y el Caribe”, Inter-American Development Bank (IDB), 21 April [online] https://blogs. iadb.org/gestion-fiscal/es/politica-y-gestion-fiscal-durante-la-pandemia-y-la-post-pandemia-en-americalatina-y-el-caribe/.

Prebisch, R. (1973), Interpretación del proceso de desarrollo latinoamericano en 1949, Santiago, Economic Commission for Latin America and the Caribbean (ECLAC), February.

Reinhart, C. and K. Rogoff (2020), "Suspend emerging and developing economies' debt payments", Project Syndicate, New York, 13 April [online] https://www.project-syndicate.org/commentary/suspend-emergingand-developing-economies-debt-payments-by-carmen-reinhart-and-kenneth-rogoff-2020-04.

Thorp, R. (ed.) (1988), América Latina en los años treinta: el papel de la periferia en la crisis mundial, Mexico City, Fondo de Cultura Económica. 
UNCTAD (United Nations Conference on Trade and Development) (2020a), "The COVID-19 shock to developing countries: towards a 'whatever it takes' programme for the two-thirds of the world population being left behind", Trade and Development Report Update (UNCTAD/GDS/INF/2020/2), Geneva, March [online] https://unctad.org/en/PublicationsLibrary/gds_tdr2019_covid2_en.pdf.

- (2020b), "From the great lockdown to the great meltdown: developing country debt in the time of COVID-19", Trade and Development Report Update (UNCTAD/GDS/INF/2020/3), Geneva, April [online] https://unctad.org/en/PublicationsLibrary/gdsinf2020d3_en.pdf.

United Nations (2020), Policy Brief: The Impact of COVID-19 on Latin America and the Caribbean, New York, July. (1955), Foreign Capital in Latin America (E/CN.12/360), New York.

World Bank (2020), Commodity Markets Outlook: Implications of COVID-19 for Commodities, Washington, D.C., April. WTO (World Trade Organization) (2020), "Trade set to plunge as COVID-19 pandemic upends global economy", Press Release (Press/855), Geneva, 8 April [online] https://www.wto.org/english/news_e/ pres20_e/pr855_e.pdf. 